\title{
Development of the cerebellar white matter is impaired by postnatal hyperoxia and protected by minocycline
}

\author{
Thomas Schmitz ${ }^{*}$, Till Scheuer, Christoph Bührer \\ From 50th Workshop for Pediatric Research \\ Gottingen, Germany. 20-21 March 2014
}

Brain injury of preterm infants has widely been ascribed to the cerebrum, but recent studies demonstrate that injury of the cerebellum occurs, too [1]. Causes of cerebellar pathologies in preterm infants and ways of protection are underinvestigated. In general, perinatal infection/inflammation, hypocarbia, and hyperoxia are factors associated with brain damage in preterm infants $[1,2]$. We investigate whether oxidative stress induced by postnatal hyperoxia impairs the development of the cerebellar white matter.

We used a neonatal hyperoxia model in rats with $80 \%$ oxygen exposure for $24 \mathrm{~h}$ from P6 to P7, and determined development and maturation of oligodendroglial precursor cells (OPCs) in the cerebellum after recovery in room air until P9, P11, P14, and P30.

Volume of the cerebellum measured by MRI in P30 rats after exposure to hyperoxia was significantly reduced as compared to control litters always kept in room air (hyperoxia $=209 \mu \mathrm{L}$, controls $=232 \mu \mathrm{L} ; \mathrm{n}=8$, $\mathrm{t}$-test $\mathrm{p}<0.05)$. Myelination measured by MBP expression in immunostainings and Western blots was significantly reduced from P7 to P30. Numbers of apoptotic TUNEL +NG2+ OPCs were higher in hyperoxia rats; OPC proliferation and maturation towards $\mathrm{CC} 1+$ stages were significantly reduced. Analysis of Iba1 immunostainings and of inflammatory cytokine expression did not reveal signs of microglial activation after hyperoxia. Oxidative stress after hyperoxia was indicated by increased nitrotyrosin. Treatment with minocycline significantly attenuated toxic effects of hyperoxia.

Postnatal hyperoxia in rats causes critical features of cerebellar pathology seen in preterm infants. A pharmacological approach for prevention seems feasible.
Published: 11 September 2014

\section{References}

1. Volpe JJ: J Child Neurol 2009, 24:1085-1104.

2. Deulofeut R, et al: Acta Paediatr 2007, 96:990-994.

\section{doi:10.1186/2194-7791-1-S1-A6}

Cite this article as: Schmitz et al:: Development of the cerebellar white matter is impaired by postnatal hyperoxia and protected by minocycline. Molecular and Cellular Pediatrics 2014 1(Suppl 1):A6.
Submit your manuscript to a SpringerOpen ${ }^{\circ}$ journal and benefit from:

- Convenient online submission

- Rigorous peer review

- Immediate publication on acceptance

- Open access: articles freely available online

- High visibility within the field

Retaining the copyright to your article 